\title{
WHO CONTROLS THE ARAB PUBLIC SPHERE IN THE ERA OF NEW MEDIA, THE NEW REVOLUTIONISTS OR THE DEEP STATE?
}

\author{
Nawaf Abdelhay Altamimi \\ Assistant Professor- Journalism Program \\ Doha Institute for Graduate Studies, Doha
}

\begin{abstract}
Recent events in Arab countries, particularly in Tunisia, Egypt have shown that new modes of communications such as Mobile phones and social networking sites have facilitated civil society's organization by allowing a timely exchange of opinions and ideas. Youth protesters in uprising societies have recognised the value of Mechanisms in which the public can meet and discuss and share ideas openly, recognise problems and suggest solutions (Caplan and Boyd, 2016). Those Young demonstrators have taken to social media such as Facebook and Twitter online to organise social prodemocracy movements andStart the revolution, demonstrating how the Web based platforms have become a crucial alternative media instrument for advocacy in today's Digital Age. (Kenix, 2009).

In contrast, when political regimes, or so called Deep State, realized the influence of social media and modern means of communication in mobilizing the public sphere, they were quick to take measures to control this sphere and to seize it with coarse and soft tools, some of it conventional and others innovative, commensurate with the digital age. Thus, the E-public sphere has become another arena for confrontation between rebellious youth seeking political democracy on one side, and totalitarian dictatorships that reject change and suppress public freedoms on the other side.
\end{abstract}

The study concludes that the spread and increasing use of emerging data and communication technologies has a small influence on societal and political changes in the Arab world as the totalitarian dictatorships that reject change and suppress public freedoms made a fast comeback to maintain their domination.

Keywords - Public sphere, Arab uprising, Deep state, Social media.

\section{INTRODUCTION}

The rise in social platforms such as Facebook, Twitter, YouTube, and other similar connecting platforms has allowed their users to exchange thoughts and connect in a way that was not possible before. This sudden rise has disrupted the existing media and even social structures. Jenkins (2006) calls this the rise of "participatory culture" in which ordinary people can create their own content and distribute it via social networks. Such changes may reflect what Castells (2007) called the emergence of "mass self- communication," which can be a new means for social movements and activists to exercise and create new forms of power. In his new book Castells (2009) focuses on the role of communication networks in power-making in society, with an emphasis on political power making. He defines power as the relational capacity that enables a social actor to influence asymmetrically the decisions of other social actor(s) in ways that favour the empowered actor's will, interest and values' (p. 10). Shirky (2008) argues that today These forms of groups are easier than ever to create using online networking tools to partake in nonhierarchical and participatory group behaviour.. According to Monroe Price, a director of the Centre for Global Communication Studies, University of Pennsylvania "we will have new models of politics, new concepts of involvement, new technologies that create these changes, and we may have huge tension in our societies" (Price, 2010, cited in Fitri. 2011).

Ho (2002) suggest that "the advent of the Internet has renewed attempts to examine how the rapid expansion of information and communications technologies has influenced the development of the public sphere" (p: 128). In a number of social and political movements, researchers from fields such as communication, economics, and political science have researched the use of social 
media. According to Brunstibg (2002, cited in Fitri, 2011) the internet is a great tool for generating popular support for activist causes in a non-violent way, as he stated "the internet changes the nature of collective action, but contrary to popular belief, the internet would appear to be especially suited of collective action rather than confrontational action." Therefore, the internet permits an unprecedented empowerment of the individual.(Fitri. 2011)

Danning (1999) agrees and asserts, "the internet is clearly changing the landscape of political discourse and advocacy. It offers new and inexpensive methods for collecting and publishing information, for communicating and coordinating action on a global scale, and for reaching out to policy makers, supports both open and private communication (cited in Fitri. 2011). Bimber and Copeland (2011) emphasized on the role of new media for providing the platform for political participation and changing their political efficacy.

Hence, the Internet is not only a welcoming of global communication forum for the free exchange of views, but it has its own class of warriors dedicated to protecting free speech online.

Langman (2005) argues that computer-savvy activists use the Internet to initiate and organize a broad spectrum of dissention activities, including consumer boycotts and public protests and demonstrations. Numerous scholars, in fact, have pointed to new communication technologies particularly social media like short messaging services (SMS), social-networking sites, and blogs as being, collectively, an important new resource for the successful organisation and implementation of social movements (Wasserman, 2007). Experts theorized about the promises of social networking technologies, including their ability to influence a participatory governance model, grassroots civic engagement, new social dynamics, inclusive societies. In addition to supporting political and social movements in more ways that are conventional by providing opportunities for political expression, symbolic identification for collective actors, and information exchange, these new communication technologies may serve a novel instrumental function.

While some studies showed that the use of social media has a strong influence on the political participation, others did not approve any correlation between the two constructs (Baumgartner \& Morris, 2010). Some have asserted that new digital media have positive effects on political participation (Hendricks \& Denton, 2010; Norris, 2001), while others have seen them as predominantly entertainment oriented. (Baumgartner \& Morris, 2010; Bimber, 2001; Prior, 2007; Putnam, 2000). In spite of the argument among scholars, the recent developments in Arab countries, particularly in Tunisia, Egypt, and most recently Sudan have shown that new communication channels (mobile phones, social networks) have facilitated the organisation of civil society by allowing a timely exchange of opinions and ideas. Youth protesters in uprising societies have recognised the value of having mechanisms by which the public can come together to freely discuss and exchange ideas, identify problems and propose solutions (Caplan and Boyd, 2016). Those youth protesters have turned to online social media like Facebook and Twitter to mobilize pro-democracy social movements and start revolution, illustrating how, in today's Digital Era, the Internet has become a key alternative media tool for activism (Kenix, 2009).

In contrast, when political regimes realized the influence of social media and modern means of communication in mobilizing the public sphere, they were quick to take measures to control this sphere and to seize it with coarse and soft tools, some of it conventional and others innovative, commensurate with the digital age. Thus, the E-public sphere has become another arena for confrontation between rebellious youth seeking political democracy on one side, and totalitarian dictatorships that reject change and suppress public freedoms on the other side.

The paper is discussing the opportunities brought by the new social media and communications tools for societies in the Arab world, in terms of their potential to enable new forms of communication and develop new public spheres. Subsequently, does the popular movements in Arab countries, which 
coincide with the technical developments in the field of communications and media, have caused any changes in the structure of the public sphere? This question stems from three hypotheses:

- Optimistic hypothesis: the new media has expanded the public sphere and raised the pace range of political participation

- The pessimistic hypothesis: the new media expanded political participation in form only but expanded the circle of silence.

- The third hypothesis: the new media did not make any fundamental changes in the structure of the public sphere, political participation of public opinion remained limited, and the state remains having the upper hand.

\section{Theoretical background:}

Jürgen Habermas published his critical investigation and analysis of the public sphere in civil society in 1962. He wrote "The Structural Transformation of the Public Sphere" describing the evolution from opinion to public opinion and the socio- structural transformation of the latter. His main intention is to explore the status of public opinion in the practice of representative government in Western Europe. According to Habermas, the public sphere is the "realm of our social life in which something approaching public opinion can be formed," and is the space which mediates between "society and state", in which the public organizes itself as the bearer of public opinion. The ideal public sphere, according to Habermas, would contribute to democracy, and is not shaped by but is facilitated through media, greater access to information, and more robust discourse and debate about common issues in democratic societies. Habermas criticized the mass media in late capitalism, which, he argued, had become dominated by government and corporate interests, leading to a top-down shaping of public opinion to meet the needs of those in power.

The appearance of the new media and the development in the communication technology have brought huge transformations even in the conceptual term of public sphere and public discourse. The development of new technologies such as communication and the rise of the new media based on Web 1.0 and Web 2.0, brought another new dimension in the discussion of the public sphere. Social Media make it possible for the transmitter and the receiver of the message to communicate in a higher level. In contrast, virtuality serves as an inducement mean for the users in the social network to be near the participators in the process of communication.

Yochai Benkler highlighted the emergence of a networked public sphere as "The easy possibility of communicating effectively into the public sphere allows individuals to reorient themselves from passive readers and listeners to potential speakers and participants in a conversation"(Benkler 2006, 213). He adds, "The network allows all citizens to change their relationship to the public sphere. They no longer need be consumers and passive spectators. They can become creators and primary subjects. "It is in this sense that the Internet democratizes" (Benkler 2006, 272). Zizi Papacharissi describes the emergence of a "virtual sphere 2.0", in which citizen consumers participate and express "dissent with a public agenda [...] by expressing political opinion on blogs, viewing or posting content on YouTube, or posting a comment in an online discussion group" (Papacharissi 2009, 244). These new social dynamics inevitably influence the way citizens become politically involved, and the way individuals negotiate their views on public matters to produce some form of public opinion. Moreover, with the emergence of social dynamics the individual identities become more visible within social groups stimulates political engagement, as it provides the satisfaction of being part of an ideological movement whilst freely expressing one's personality. Manuel Castells stresses the novelty of this sphere: "The construction of the new public sphere in the network society proceeds by building protocols of communication between different communication processes" (Castells 2009, 125).

\section{The Arab public sphere}

It can be seen, as a clear description of the political regimes in some Arab nations, which were once there,that those regimes typically aimed to restrict and influence the public domain in their favour. As Lynch (2015) asserted, it would be difficult to consider it an actual public sphere in the sense intended by Habermas. Participation was limited to state 
mouthpieces with virtually no opportunity for critical engagement or debate in which the public could discuss political matters.

Those political regimes had used the properties of the state to maintain a paternalistic system of government in which democracy and human rights values are subordinated (Lynch, 2015). Almost every country in the region was dominated by stateowned or controlled media that exercised an iron grip over public political expression. Through this, they portray an image of wellbeing and high quality living standards," which would actually encourage anything but a revolution. The Arab world of these decades was the epitome of politics in the absence of a public sphere. Political regimes vary in the degree to which they enable voters to participate meaningfully in the system.

Freedom of speech is an important topic that shapes the nature and type of the media in the Arab world.. Freedom of speech is, as in most areas of the globe, part of the national, legal, cultural and economic climate. Civil societies view press freedom as one of the constitutional rights of an independent, equal and democratic society. The Universal Human Rights Declaration indicates: "Everyone has the right to freedom of opinion and expression; this right includes freedom to hold opinions without interference and to seek, receive, and impart information and ideas through any media regardless of frontiers".(Johnston, 1998; Walters and Quinn, 2003 cited in Quinn et al, 2004).

Ibn Khaldun Centre for Development Studies' annual report on Civil Society and Democratization in the Arab World 2010 asserts that:

"All Arab countries continue to criminalize press offences-where offences are interpreted expansively. Thus Egypt, Libya, Saudi Arabia, Syria, Tunisia, and to a slightly lesser degree, Algeria, Jordan, Morocco, and Yemen, are all zealously hauling journalists to court where they are sentenced to prison terms for having spoken out freely criticizing the regime or the ruling elites. As noted by Freedom House the "media in the region is constrained by extremely restrictive legal environments in which laws concerning libel and defamation.... hamper the ability to report freely." Of particular concern in this regard are Egypt, Libya, Syria Tunisia and Saudi Arabia".

In the 1990s, there were some tentative signs of the rise of public sphere sites, particularly in countries that underwent limited political openings in the early years of the decade (Lynch, 2015). The launch of Arab satellite channels including the Qatar-based channel Al-Jazeera, Al Arabiya, and many more channels, have changed the media landscape and brought about a small revolution in the region. This news channel has opened a new era in many countries of the region for independent news coverage and a new sense of freedom. By airing highly controversial political debates, using a provocative tone and addressing sensitive social, economic and political issues, something unheard of until then, it has successfully attracted the attention of millions of viewers in the region and in the world. Its attempt to provide an objective, reliable and professional news coverage outside the influence of governments and outside a western cultural framework has won the respect of many media experts. The spread of these new technologies in the Arab region has inevitably caused the birth of dozens of new television channels with new messages and information for a new Arab audience. For the first time journalists and media operators found a "public free space" where they can broadcast different voices of those of governments, freely or at least more freely than before. During the second half of the 90s, this huge process of new technologies of transmission increased the debate between people, scholars and associations about the principle of the press freedom and the promotion of an independent, free and pluralistic Arab media.

\section{New media - new generation}

Text messaging, blogs, photo-sharing sites and social networking sites are increasingly popular in the Middle East as internet connectivity rates improve and mobile technologies bypass the need for internet access. Digital news consumption across the Arab region is high and growing. Over threequarters of nationals get news on their phones and two thirds do so at least once a day $(77 \%$ 
at all, $67 \%$ daily). Using smartphones for daily news checks is second only to accessing news on TV (78\% TV). Dennis et al, 2017). There are now more than 100 million Arab social media users in the MENA region and around 320 million mobile phone subscriptions. The ICT usurer's number is likely to continue to rise, especially with the introduction of technologies that overcome poor ICT infrastructure that hinders Internet access in the region. Demographic factors are also expected to contribute to the growth of Internet population. The Arab Media Outlook 2008-2012 says that, "Digital media will thrive in the Arab market because the market has a large, technologically accomplished demographic group-its youth-who are comfortable with it and will customize it to their own requirements.

New technologies, communications tools, and social networks have played fundamental roles in the current Arab people Uprising. It can be argued that the first and most important is that it has given the public the courage and permission to cross this once tall wall of fear, built by the government; whereby, if you openly opposed government regime you would inevitably have to face harsh consequences. Secondly, the internet has served as a means to spread information and challenge government-imposed media controls providing the activists with new means and tools to use when organising demonstrations, in sending short updates to journalists, bloggers and activists, and in encouraging media coverage.

In the revolutions of 2011, many young Arabs turned to participatory and social media in conjunction with real-world organizing and demonstrating. This participatory media were used as platforms for political activism, and activists had increasingly employed it to compliment real-world actions. Social media and especially social networking sites such as Facebook and Twitter were largely responsible for the organization of Anti-regime protests and riots across the Arab world.

Revolutions of 2011 and beyond demonstrate the opportunities offered by social media for large-scale mobilization and the organisation and implementation of social movements. Moreover, the link between the new media and the mass media has also been a critical factor in sustaining the momentum of the struggle for change. Social media introduced speed and interactivity that were lacking in the traditional mobilization techniques, which generally include the use of leaflets, posters, and faxes. Additionally, the use of social media helped to draw local and international attention to important activities that otherwise may have been shielded from public view, thereby isolating the participants. People used this tool and means to communicate their message to mass numbers so that the biggest number of people could hear about the next event or protest. Sites such as Facebook, have actually been able to overcome what once seemed to be the biggest power in these countries, the government regime.

\section{Who control the new Arab public sphere?}

During the revolutionary heat of January and February 2011, the Arab public sphere became a force unto itself, a carrier of modular protest forms and slogans that spanned borders and overwhelmed the repressive power of states (Lynch, 2015). The Arab uprising of 2011 offered a rare glimpse of transnational revolutionary solidarity, a pure expression of popular mobilization around a shared set of political demands. Arab publics have been dramatically empowered (Lynch, 2015). The following years witnessed the systematic degradation, division, and dismissal of that public sphere. The E-public sphere became a main arena for political confrontation and a key source of the polarization, fear, and uncertainty that undermined democratic transitions. The Arab public sphere has been recaptured as a mobilisation tool for regimes (Lynch, 2015). Mohamad Najem, executive director at Beirut-based SMEX, a digital rights organisation focusing on issues related to freedom of expression, online privacy and safety, said social media movements had taken the Middle East by surprise and governments adapted relatively quickly, using social media against protesters and civil rights activists. ${ }^{1}$

Within weeks of the revolutionary fever's onset in January 2011, Arab states were already figuring out how to turn its popularity and influence to their advantage or, at least, how to deflect its power. The regimes that survived the initial onslaught systematically clawed back their places of power within the public sphere, recolonizing those zones of public discourse that had been seized by 
activists and restoring the censorship, divisions, and fear that had inhibited such popular challenges in the past. under the pretext of protecting the state's authority and prestige, maintaining public order, protecting public interests and national security each of these regimes sought to create a legal framework that enables it to restrict freedom of expression and access to public and political spheres-namely the right to stage marches, protests, and public gatherings. For example, but not limited, Egypt's has passed a controversial law that allow the state to regulate social media users. In August 2018, the president signed the new Law on Combating Cybercrimes, which creates a legal framework to block websites deemed to threaten national security. Individuals who visit banned websites may be jailed for up to one year, while creators or managers of websites that are later banned could face up to two years in prison. ISPs are required to retain browsing data of their customers and disclose it to security bodies upon request. Parliament also approved three draft laws regulating the media in June 2018. The laws contain number of new restrictions on online media, for example, stipulating that no websites may be set up or managed in Egypt without a license from the Higher Council for Media Regulation. Under the law, a personal social media account, blog or website with more than 5,000 followers could be considered a media outlet and subject to media law, therefore they could face fines or be blocked if they are considered a "threat to national security". Egypt's internet freedom is poised to decline further with new legislation ${ }^{2}$ and Internet freedom further declined in 2018 as online censorship increased dramatically. ${ }^{3}$ Mohamad Najem, said: "The online sphere we used to go to in the Middle East to express ourselves, to talk about politics, has started to close down slowly because of all these regulations". ${ }^{4}$

Moreover, where regulation fails, some states resort to internet shutdowns or deliberate disruptions. An internet shutdown can be defined as an "intentional disruption of internet or electronic communications, rendering them inaccessible or effectively unusable, for a specific population or within a location, often to exert control over the flow of information. ${ }^{5}$ In 2018, the global KeepItOn coalition documented more than 196 internet shutdowns around the world. ${ }^{6}$ Governments often claim that internet access is blocked in the interest of public security and order. Internet shutdowns or disruptions usually take three forms. The first and probably the most serious is where the state completely blocks access to the internet on all platforms. The second way that governments restrict internet access is by applying content blocking techniques. They restrict access to particular sites or applications. This is the most common strategy and it is usually targeting social media platforms. The idea is to stop or limit conversations on these platforms. Internet censorship remains one of the most common methods of state control over the media. Reasons for filtering cyberspace include ensuring the security of the current regime, attempts to limit all kinds of opposition movements, and the protection of the religious and moral norms of society. The third strategy, done almost by stealth, is the use of what generally known as "bandwidth throttling". In this case, telecom operators or internet service providers forced to lower the quality of their cell signals or internet speed. This makes the internet too slow to use. "Throttling" can also target particular online destinations such as social media sites (Ogola, 2019). A selective level of website filtering is present in Libya, Sudan, Kuwait, Bahrain, Oman, Mauritania, Qatar, and Jordan, while, Internet censorship and blocking in Egypt escalated to unprecedented levels in 2018, as part of a wider crackdown on freedom of expression and civil society in advance of the March 2018 presidential elections. As of February 2018, around 500 websites were reported blocked, many of which had been blocked since the beginning of 2017.7 There are three basic prerequisites for Internet filtering methods, in the Arab countries, mainly: to maintain political stability; to strengthen national security; and to preserve traditional social values. ${ }^{8}$

Governments used other methods and tactics such flooding the public sphere and media climate with huge number of satellite channels with trivial content. Golding (1990) identifies technological convergence and media ownership as major threats to social rights in communication (Boeder, 2005). According to Habermas, the emergence of the mass press is based on the commercialisation of the participation of the masses in the public 
sphere. Consequently, this 'extended' public sphere lost much of its original political character in favour of commercialism and entertainment. The mass media, Habermas argues, have mutated into monopoly capitalist organisations. Their role in the public debate has shifted from the dissemination of reliable information to the formation of public opinion; political system can use propaganda to create, modify, change or deceive public opinion. This led Habermas to the conclusion that "The world fashioned by the mass media is a public sphere in appearance only".

In parallel to that, governments injecting millions of dollars to dilute the public sphere by produce and broadcast entertainment programs that dumbing down content for young audiences and distract people from participating in public life. Thus, the techniques of advertising and publicity have invaded and corrupted the public sphere, as the public sphere declined; citizens became consumers, dedicating themselves more into passive consumption and private concerns than to issues of the common good and democratic participation. Kellner (1990) contend that the media, state, and business are the major institutional forces of contemporary capitalist societies. He added that "mediate" between state, economy, and social life, and that the mainstream broadcasting media have not been promoting democracy or serving the public interest and thus are forfeiting their crucial structural importance in constructing a democratic society. Hence, he assumes that the communication media are something like what Habermas calls "steering media" (Boeder, 2005). For Habermas, the "steering media" of money and power enable business and the state to control ever more processes of everyday life, thus undermining democracy and the public sphere (Boeder, 2005).

Moreover, governments employed and deployed automation and bots to sway public opinion and to sabotage the E-public sphere. Bots, defined by Phil Howard as "chunks of computer code that generate messages and replicate themselves," are becoming a key part of political communication on social media platforms and on message boards. Bots and fake accounts used to flood the E-public sphere with a particular topic and make it appear more popular, which further push political messages into public view. Moreover,
Bots, Botnets, and Trolls used to Shift conversation quickly and swiftly, through increasing "noise" and making it harder for interested individuals to find relevant information, or through inserting doubt and new questions into political conversations, that posits two or more competing views against each other (Caplan \& Boyd, 2016). In October 2019, buzzfeednews reported that Facebook and Twitter shutdown hundreds of fake accounts using the platform for propaganda. ${ }^{9}$ Ritzen and Yarno (2019) confirmed that Twitter in the Middle East changed from a tool for transparency to a platform rife with propaganda and fake accounts. (Ritzen and Yarno, 2019).

These automated processes can be used also to push people 'fall silent about their political opinions' (Turner \& Sparrow, 1997:122) and remain silent if they consider that their views are those of the minority (Liu \& Fahmy, 2011:45), because they fear isolation (Kennamer, 1990). According to the "Spiral of Silence theory" (Developed in the 1970s by Elizabeth Noelle-Neumann) individuals use a 'quasistatistical sense' to determine whether their opinions are popular or unpopular (Hayes, 2007:785). If they perceive that they share their opinions with the majority, they may be willing to speak out. Alternatively, if they perceive their opinions to be those of the minority, they will keep silent or conform to the majority view (Liu \& Fahmy, 2011:46). Thus, the state flooded the public sphere with what Habermas calls "no public opinion" and at the same time expelled real public opinion outside the public sphere through a spiral of silence.

States also sought to create new public opinion leaders, known as "influencers", and entrusted them with tasks such as guiding public opinion, engaging public opinion, especially young people on minor and marginal subjects, and distracting young people from public issues. The new influencers were manufactured and promoted in attempt to replace the traditional public leaders; Party leaders, leaders of popular organizations, trade unionists, intellectuals, the activists ... etc. (Habermas, 1991) emphasised that manufacturing of representation (based on annexation rather than argumentation) create an environment with 'no public opinion' (Huberman, 1991, p. 178). So, one of the 
threats to critical civil society is an environment saturated with 'no public opinion'. (Ortiz, 2015)

Using these tools and approaches, the state in power is trying to control the virtual public sphere, just as it has taken control of the public domain. Egyptian security forces, for example, blocked access to Cairo's Tahrir Square, the highly symbolic focal point of the 2011 revolution, after a series of social media videos posted by Mohamed Ali, a former military contractor living in self-imposed exile in Barcelona who called for a million Egyptians to march against the president, Abdel Fatah alSisi on Friday, 27th September 2019. In similar way, former Sudan president Omar al-Bashir cut the internet for 68 straight days during 2018, according to Netblocks, which monitors internet freedom. Netblocks reported that in June 2018, the government in Sudan began a days-long "throttling" of the country's internet, meaning the internet services technically remained online, but the capacity of the biggest major network gateways were reduced and outages affected the "edge" of the network. The takedown coincided with reports that more than 100 pro-democracy demonstrators were killed by paramilitaries in Khartoum, as the military government there tries to solidify its control. ${ }^{10}$
Analysis:

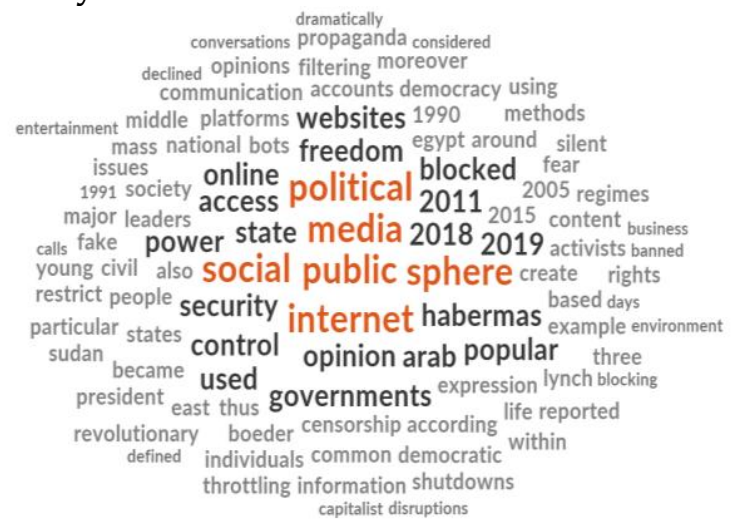

By analyzing the literature mentioned above by using the Nvivo software following things were noticed:

The very first thing that came up with the analysis was the treemap. In the treemap, it can be seen the words social, public, internet, political, and media are highlighted in orange colors and rest in black. The orange color shows that these words appeared the most during the discussion. With the positioning of words, it can be deduced that social-publicinternet shares closer proximity than political. It can state that the effect of the internet on the public sphere was greater than that of political. It means that during the revolution,

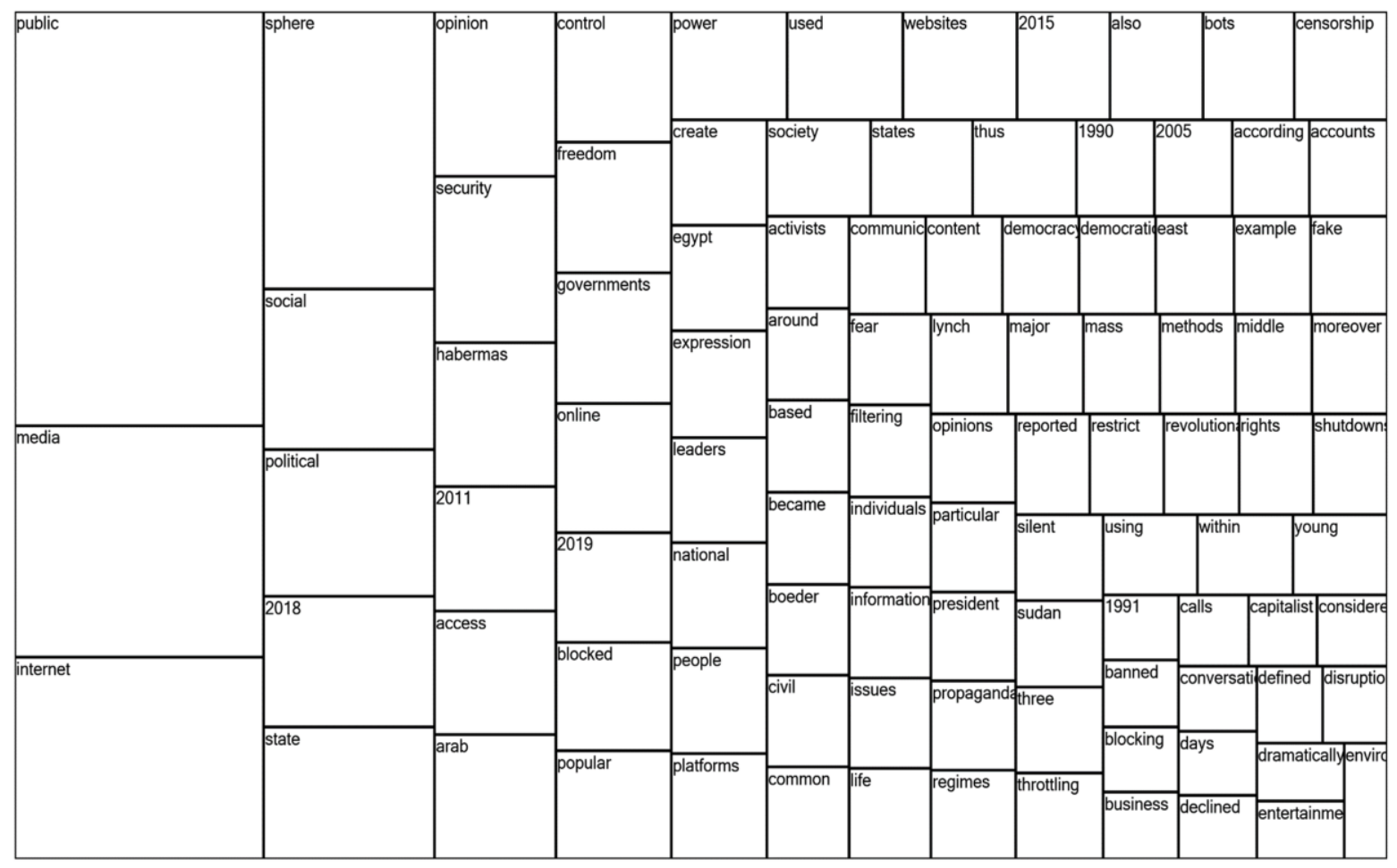


social media played a better role in connecting the audience. Still, it should be noted that the difference between the internet and political is not much when compared public. So, yes, the political party also used the tool but not as much as the public used social media.

In the word tree above, which is generated by Nvivo, the most portion is covered by the public, then media, and then the internet. In the second row comes social, political, and state. This analysis suggests and supports the claim made earlier that the internet's coverage and influence were more than the state and politics.

\section{CONCLUSION}

The Arab world has seen and is continuing to see drastic changes in old and dormant regimes, but the consensus across these revolutionized countries is that this new media, in the hands of normal people, has been a part of the change, and without it; their revolutions may not have succeeded. The growth of social media in the region and the shift in usage trends have played a critical role in mobilization, empowerment, shaping opinions, and influencing change. Moreover, it is clear that political communication via participatory media was amplified with a new intensity that pushed individual voices beyond activists' personal ties to larger networks and as political tools able to achieve significant results; first, they bring together otherwise remote and disparate groups. Second, they create channels to bypass traditional state control of the media so the outside world can see what is going on. Thirdly, the use of mobile and internet technologies has given the elite, middle class and youth new tools for political organisation, mobilisation and advocacy (Hofheinz, 2011: Wall, 2011: Niekerk, et al. 2011). No doubt, that the Arab uprising of 2011 will surely be marked in history as a revolution that was shaped by new media, and the latter will continue to play a growing role in political, societal and economic developments in the Arab region.

On the other hand, Arab governments' reactions to this new phenomenon are mixed. While some governments tried to resist change, and to strangle the new forms of informational flows emerging in their societies - by blocking access to social media websites, the internet or mobile networks altogether - a few were more responsive and started adapting to the changes. These more responsive governments tried to limit the advantage of the growth of social media usage among the mostly young population by putting new guidelines and policies in place. Another type of Arab government chose to join the game after failing to beat the new players or impose its rules. The latter type of governments employed the technology available to create a fake or a No public opinion and to isolate the real opinion of real people.

Despite all government strategies and efforts to have, and maintain control of the mass media, and even social media in their countries; it seems even they were surprised with events in the most recent years leading up to the shift of control from people in power to the power of people, and consequently the successive waves of Arab uprising. In sum, one should agree with Lynch (2015:332) that "the Arab public sphere will be torn for many years to come between the restless, critical power of the public sphere and the determined efforts of regimes, states, and old elites to maintain their domination" (P.332).

\section{REFERENCES}

Abdelhay, Nawaf. (2012), "The Arab uprising 2011: new media in the hands of a new generation in North Africa", Aslib Proceedings, 64:5, pp. 529-539. https://doi.org/10.1108/

00012531211263148

Alidina, Abbas. (2010), 'MENA Facebook Digest- Tracking Facebook Usage in the Middle East \& North Africa', http://logicks.com/pdf/2010-05-22MENA_Facebook_Digest.pdf. .

Al-Jazeera war given an Award for Best Circumvention of Censorship, by Index on Censorship in March 2003, see: Free speaking voices in the wilderness. Available from: http://www.index online.org/awards_2003.shtml. .

Al-Obaidi, Jabbar Audah (2007), Media Censorship in the Middle East, Lewiston: Edwin Mellen Press.

Baumgartner, Jody. C and Morris, Jonathan. S (2010), ‘My FaceTube Politics, Social Networking Web Sites and Political 
Engagement of Young Adults', Social Science Computer Review, 28:1, pp.24-44.

Benkler, Yochai. (2006), The Wealth of Networks. New Haven, CT: Yale University Press.

Bimber, Bruce, and Copeland, Lauren. (2011), Digital media and political participation over time in the US: Contingency and ubiquity. Paper prepared for presentation at the Annual Meeting of the European Consortium for Political Research, Reykjavik, Iceland. https://ecpr.eu/ Filestore/Paper Proposal/db466b6c-9c164491-b92a-32f1b0e 80273.pdf.

Boeder, Pieter. (2005), 'Habermas' heritage: The future of the public sphere in the network society',10: 9, https:// firstmonday.org/ article/view/1280/ 1200. [Accessed 27 May 2019].

Bryant, Martin. (2011), ‘Facebook and Twitter unblocked, but Google and YouTube still blocked for many in Egypt. The Next Web'. http://thenextweb.com/me/2011 /01/26/googleyoutube-twitter-andfacebook-now-all-blocked-in-egypt. .

Castells, Manuel. (2007) 'Communication, power and counter-power in the Network Society'. International Journal of Communication, 1, 238-266. http:// criticaltheoryindex.org/assets/castellsma nuel_communication \%2C-power-andcounter-power-in-the-network-society. pdf. [Accessed 12 September 2019].

Castells, Manuel (2009), Communication Power. Oxford, New York: Oxford University Press.

Caplan, Robyn, and Boyd, Danah. (2016), 'Who Controls the Public Sphere in An Era of Algorithms? Mediation, Automation, Power', May 2016. https://datasociety.net/pubs/ ap/MediationAutomationPower_2016.pd f. [Accessed 12 September 2019].

Çela, Erlis (2015), 'Social Media as a New Form of Public Sphere', European Journal of Social Sciences Education and Research, 2:3, pp. 195-200.

Cortright, David. (2007), 'The movement against war in Iraq', Nonviolent Social Change: The Bulletin of the Manchester College Peace Studies Institute.

http://www.manchester.edu/academics/dep artments/peace_..
Della, Porta, D., and Mosca, Lorenzo. (2005), 'Global net for global movements? A network of networks for a movement of movements', Journal of Public Policy, 25:1, pp. 165-190.

Dennis, Everette, E., Martin, Justin. D., and Wood, Robb. (2017), 'Middle use in the Middle East, 2017: A seven-nation survey', Northwestern University in Qatar. Retrieved from www.mediaeast media.org/survey/2017. (monograph). .

Edwards, Jim (2019). All the countries where someone managed to shut down the entire internet - and why they did it? https://www.businessinsider.com/coun tries-internet-shutdown-statistics-2019-6

Fitri, Nofia. (2011), ‘Democracy Discourses through the Internet Communication: Understanding the Hacktivism for the Global Changing'. Journal of Communication and Media Technologies, 1:2. http://www.ojcmt.net/articles/121.pdf..

Hafez. Kai, (2010), 'How Liberal is Soft Authoritarianism when Compared to Democracy? Arab and Western Media Systems Typologies', Paper Presented at the Arab Media Symposium: Information Evolution in the Arab World Georgetown University, Washington, DC 22 March 2010.

https://www.uni-erfurt.de/fileadmin/userdocs/philfak/kommunikationswissensch aft/files_publikationen/hafez/HAFEZ_2 010_Georgetown_paper.pdf [Accessed 10 September 2019].

Hayes, Andrew. F. (2007), 'Exploring the forms of self-censorship: On the spiral of silence and the use of opinion expression avoidance strategies' in Journal of Communication, 57: 785-802.

Hendricks, John. A., and Denton, Robert. E. (2010), Communicator-In-Chief: How Barack Obama used new media technology to win the White House. Lanham, MD: Lexington.

Ho, K.C, Baber, Z. and Khondker, HH. (2002) "'Sites' of Resistance: Alternative Websites and State-Society Relations" in British Journal of Sociology. Vol. 53, No.1, pp $127-148$

Hofheinz, Albrecht. (2011), 'Nextopia? Beyond revolution 2.01.' International Journal of Communication, 5 (2011), pp. 1417-1434: https://www.researchgate.net/publicati 
on/259254182_Nextopia_Beyond_Revolu tion_201.

Jenkins, Henry. (2006), Confronting the challenges of participatory culture: Media education for the 21st century, Chicago: MacArthur Foundation.

Johnston, Carla. B. (1998), Global News Access. The Impact of New Communications, Westport, Connecticut: Praeger.

'Media outlook 2008-2012, Collaborating for growth Forecasts and analysis of traditional \& digital media in the Arab world'. http://www.pwc.com/gx/en/ entertainment-media/pdf/arabmedia outlook.pdf.

Kenix, L. Jean. (2009), 'Blogs as alternative', Journal of Computer-Mediated Communication, 14:4, pp. 790-822.

Kennamer, J. David. (1990) 'Self-serving biases in perceiving the opinions of others: Implications for the Spiral of Silence' in Communication Research, 17:3, pp.393-404.

Kulkarni, Anushka (2017) Internet meme and Political Discourse: A study on the impact of internet meme as a tool in communicating political satire, Journal of Content, Community \& Communication Vol. 6 Year 3.

Langman, Lauren., (2005), 'From virtual public spheres to global justice: A critical theory of interworked social movements'. Sociological Theory, 23:1, pp.42-74.

Lievrouw, Leah. A. (2011), Alternative and activist new media. Cambridge, MA: Polity Press.

Liu, Xudong., and Fahmy, Shahira. (2011) 'Exploring the spiral of silence in the virtual world: lndividuals' willingness to express personal opinions in online versus offline settings' in Journal of Media and Communication Studies, 3:2, pp. 45-57. http:/ / www.academicjournals.org/jmcs.

Lynch, Marc (2015),'The Rise and Fall of the New Arab Public Sphere'. Current History. http://www.currenthistory. com/Article.php?ID=1280. [Accessed 20 September 2019].

Marcondes de Moraes, Gustavo., Pelegrini, G.Consolmagno., and Pinheiro, G.Trindade (2020) Social media and protests engagement: what's gender got to do with it? Journal of Content,
Community \& Communication Vol. 11 Year 6.

Niekerk.V, Brett, Pillay, Kiru, and Maharaj, Manoj. (2011), 'Analyzing the Role of ICTs in the Tunisian and Egyptian Unrest from an Information Warfare Perspective'. International Journal of Communication, 5 (2011), pp. 1417-1434. http://ijoc.org/ojs/index.php/ijoc/ article/view/1186.

Noland, Marcus (2008), 'Explaining Middle Eastern Political Authoritarianism II: Liberalizing Transitions,' Review of Middle East Economics and Finance, 4:1, Article 2. http:/ / www.bepress.com/rmeef/vol4/is s1/art2. .

Norris, Pippa. (2001), Digital divide: Civic engagement, information poverty and the Internet worldwide. New York, NY: Cambridge University Press.

Quinn. Stephen, Walters. Tim and John Whiteoak. (2004), A Tale of Three (Media) Cities. Global media journal, 3:5- Fall 2004: http:/ / www.globalmediajournal.com/o pen-access/a-tale-of-three-mediacities.pdf .

Ritzen, Yarno. (2019). How armies of fake accounts 'ruined' Twitter in the Middle East. https://www.aljazeera.com/news / 2019/07/armies-fake-accounts-ruinedtwitter-middle-east-190715165620214. html

Rugh, William A. (2004), Arab Mass Media. Newspapers, Radio, and Television in Arab Politics, Westport: Praeger.

Ogola, George (2019), 'Shutting down the internet doesn't work - but governments keep doing it'. https://theconversation. com/ shutting-down-the-internet-doesntwork-but-governments-keep-doing-it111642

Ortiz, Andrés (2015),'Taking Control of the Public Sphere by Manipulating Civil Society: The Citizen Revolution in Ecuador'. European Review of Latin American and Caribbean Studies. No. 98 (2015) April, pp. 29-48.

Papacharissi, Zizi. (2009), The Virtual Sphere 2.0. The Internet, the Public Shpere, and Beyond. In Routledge Handbook of Internet Politics, eds. Andrew Chadwick and Philip N. Howard, 230-245. New York: Routledge. 
Prior, Markus. (2007), Post-broadcast democracy: How media choice increases inequality in political involvement and polarizes elections, NY: Cambridge University Press.

Putnam, Robert D. (2000), Bowling alone: The collapse and revival of American community, New York, NY: Touchstone.

Shirky, Clay. (2008), Here comes everybody: How change happens when people come together. New York: Penguin Books.

Zaki, Moheb.(2010), 'Civil Society and Democratization in the Arab World'. Ibn Khaldun Center for Development Studies. Annual Report, 2010. http:/ / www.eicds.org/ index.php?option=com_content\&view $=\mathrm{a}$ rticle\&id=49\&Itemid $=61$.

Tapping into the Middle East's Emerging Digital Media Frontier. http://www. adbookfair.com/cms/uploads/Newslett er Info_Arab_Book_final_30sept_6.pdf. Available from:

http:/ / www.internetworldstats.com/ stats5.htm. .

The Arab Advisors Group's team of analysts in the region has already produced over 2,200 reports on the Arab World's communications, media and financial markets. Reports are available from: http:/ / www.arabadvisors. com/clients.htm.

"Toward New Mass Communication: Obstacles and Challenges facing the Media in North Africa". January 13 and 14, 2007 - Cairo. Available from: http:/ / www.cihrs.org/

English/NewsSystem/Articles/324.aspx

Turner, John. and Sparrow, Nick. (1997), 'Hearing the silence: the spiral of silence, parties and the media' in Media, Culture and Society, 19: pp.121-131.

Wall, Melisssa.(2011), 'I'll Be Waiting for You Guys": A YouTube Call to Action in the Egyptian Revolution' International Journal of Communication, 5 (2011), pp. 1417-1434. http://ijoc.org/ojs/index.php/ijoc/articl e/view/1186. .
Wasserman, Herman. (2007), 'Is a new worldwide Web possible? An explorative comparison of the use of ICTs by two South African social movements'. African Studies Review, 50:1, pp.109-131.

Endnotes:

1. https://www.aljazeera.com/news/ 2019/07/arab-governments-cyber-lawsshut-activism-190717075018688.html

2. https://netblocks.org/reports/ facebook-messenger-social-media-andnews-sites-disrupted-in-egypt-amidprotests-eA1Jd7Bp

3. https://freedomhouse.org/report/ freedom-net/2018/egypt

4. https://www.aljazeera.com/news/ 2019/07/arab-governments-cyber-lawsshut-activism-190717075018688.html

5. This definition was developed at RightsCon Brussels in 2016 in collaboration with a diverse set of stakeholders including technologists, policy makers, activists, and others: https://www.accessnow.org/nointernet-shutdowns-lets-keepiton/

6. https://www.accessnow.org/cms/ assets/uploads/2019/06/KIO-Reportfinal.pdf

7. https://freedomhouse.org/report/ freedom-net/2018/egypt

8. Shishkina, Alisa, and Issaev, Leonid (2018) Internet Censorship in Arab Countries: Religious and Moral Aspects.

9. https://webcache.googleusercontent. com/search?q=cache:dSBRtwM1Ue4J: https:/ / www.mdpi.com/2077$1444 / 9 / 11 / 358 / \mathrm{pdf}+\& \mathrm{~cd}=6 \& \mathrm{hl}=\mathrm{en} \& \mathrm{ct}=$ clnk\&gl=qa https://www.buzzfeed news.com/article/janelytvynenko/uaepropaganda

10. Edwards, Jim (2019). All the countries where someone managed to shut down the entire internet - and why they did it? https://www.businessinsider.com/ countries-internet-shutdown-statistics2019-6 